\title{
WASTELAND OF POLITICAL CORRECTNESS ${ }^{1}$
}

\author{
Julienne Busic*
}

\section{The Plague of Political Correctness}

The German poet Novalis once said that "philosophy is really homesickness; it is the urge to be at home everywhere."

As far as the past few decades are concerned, Novalis is right. In the world of academia and intellectual research, two contradictory philosophies purport to provide the best and most appropriate home for the myriad contradictions of existence: political correctness, which attempts to identify truth in feeling, and deconstruction, which seeks it in objectivity.

The phenomenon of "political correctness" now so popular in the West, and especially in the United States, is based upon linguistic euphemism, the cloaking of evil, misfortune and unpleasant topics in terms designed to spare one's feelings. People do not fail in endeavors, they "underachieve". People are not fat, but "gravitationally challenged" and a corpse is not a corpse but a "non-living person". There is a mortal fear, as Robert Hughes points out in his bestseller "Culture of Complaint", that the "concrete will give offense."

1 From Croatian daily political newspaper, "Vjesnik", February 6, 1997

* Julienne Busic holds a Master's Degree in German Language and Literature and Linguistics with a minor in political science. From 1992-1995 she was an adviser in the Embassy of the Republic of Croatia in Washington, D.C. and from 1995-2000 a senior adviser in the Office of the President of the Republic of Croatia. Since 2000, she works as a writer, translator, and essayist, and her last book "Living Cells", which addressed the issue of rape as a war crime in occupied Vukovar, was awarded the A.B. Simic prize for literature in 2013. 
Facts cannot be unadorned, but must be clothed in layers of description which dilute reality. As a result, entire lines of intellectual research and areas of designation have been declared off limits. "The emphasis is on the subjective: how we feel about things, rather than what we think or can know", says Hughes. Goethe long ago identified the dangers of this turning inward: "Epochs which are regressive, and in the process of dissolution, are always subjective, whereas the trend in all progressive epochs is objective".

Which brings us logically to the subject of Dr. Tudjman's book, "Horrors of War: Historical Reality and Philosophy", which has appeared in five Croatian and one German printing, and has just come out in its first, extensively revised English edition. President Tudjman had the great misfortune of having turned his objective attention to the "offensive concrete" when he first began Horrors of War in the 1980s, which focused on the manipulations of history and victims of the Second World War. Feelings were hurt, euphemisms which he could have employed were not. Why had he written "genocidal policy" when he could have written "infelicitous activities resulting in the non-living status of a large number of individuals"? Or "distortion of facts" instead of "perhaps inadvertent or unintentional rendering of data"? Because he delved into areas which challenged accepted propaganda or endangered conventional wisdom in related areas, he found himself and his work continually attacked not by scholars but by guardians of political correctness.

Those who have followed this project for a number of years recall well the chronology of disinformation and attacks connected to this book - the Serbian mistranslations of key excerpts taken out of context, which were then distributed through Yugoslav Embassies to unsuspecting media and politicians; the intentional and careless repetition of errors of fact, even after they had been officially repudiated; the charges that President Tudjman was a revisionist and had minimized the number of victims and Croatian responsibility for them; the criticism for having included testimony by prisoners about Jewish cooperation with their persecutors in Jasenovac; and the misattribution of quotes intended to discredit President Tudjman. One such glaring example concerns the phrase "Judeo-Nazi", a formulation by the late left-wing Israeli professor and theologian, Yeshayahu Leibowitz, who used it to express his opposition - and that of many other leftist Jewish intellectuals, i.e. Professor Amos 
Funkenstein, Yehiam Weitz, Israeli historian Yigal Elam, Israeli academic Dr. Ilana Hamerman, linguist and social critic, Noam Chomsky - to Israeli treatment of Palestinians. President Tudjman was labeled a racist and anti-Semite for daring to analyze this treatment when he wrote the book in the 1980's, and then for quoting Leibowitz. Meanwhile, Leibowitz and other leftists were also labeled racists and anti-Semites by the Israeli right wing, whom Leibowitz and company had likewise criticized as racists.. One might be forgiven for being confused. In the end, however, as repugnant as the term "Judeo-Nazi" may be to most Jews and non-Jews alike, Leibowitz' reputation in Israel appears not to have suffered too greatly. He was awarded in 1993 the prestigious Israel Prize for intellectual achievement by Yitzhak Rabin's Minister of Culture, Shulamit Aloni. As Hillel Halkin writes in the conservative Jewish monthly, "Commentary", there "was nothing wrong in calling Jews Nazis, it would seem, as long as they were the right Jews."

So while President Tudjman was pilloried in the press as an anti-Semite and revisionist by those who had never read the book, others, both Jewish and non-Jewish who had read the book or who had investigated the charges, and who based their evaluations not on "political correctness" but upon scholarship and research, were of a different view. Thomas Cushman, in "Genocide After Emotion: The Postemotional Balkan War", writes about the distortions concerning Horrors of War and the unfair collective representation of the "Croatian-as-Nazi":

Tudjman's body-counting, which was meant to counter Serbian use of past genocide as propaganda to ground their own genocide, was recast by many as Holocaust revisionism. Notwithstanding the difficulty of shaking such a label in the present-day world, the accusation of revisionism could, within the context of the collective representation of "Croatian-as Nazi", be seen as further evidence of a Croatian affinity for Nazism and anti-Semitism.

Regarding charges that President Tudjman was a revisionist and has sought to minimize Croatian guilt during the Second World War:

Croatian historian and current President Franjo Tudjman, who has often been accused of whitewashing Croatian responsibility for genocide, 
has accurately described (in Horrors of War) the policy of the Ustasha dictatorship toward the Serbs in Croatia in the following terms: 'it is a historical fact that the Ustasha regime of the Independent State of Croatia, in carrying out its plans of reducing the "enemy Serbian Orthodox population in Croatian lands", committed a great genocidal crime against the Serbs, and a proportionally even greater one against the Gypsies and the Jews, in carrying out the Nazi racial policy.'

Reneo Lukic and Allen Lynch, Europe from the Balkans to the Urals: The Disintegration of Yugoslavia and the Soviet Union, (Oxford, 1996)

Norman Stone of the Faculty of History at the University of Oxford, wrote in the Times Literary Supplement of June 1I, 1993, about the distorted Yugoslav embassy translations and subsequent misrepresentations of the facts:

In the early days of the crisis, Yugoslav embassies were issuing a dozen pages of quotations from the book...one Robert Kaplan picked it up and wrote what looked to be a very damaging article in the New Republic...he later admitted that he had not read the book, nor does he seem to know the language...there were elementary mistakes in the embassy translation...quotations from Tudjman were interspersed with dots...statements that Tudjman had quoted from anti-Semites were reproduced as if they were his own words...

In another review, Jewish-American philosophy professor, Dennis Rohatyn, who read the unrevised text, writes that the book is "a masterpiece", an "important book, not least because he exposes false dichotomies, begged questions, and reification with the deftness of a logician." On the antiSemitic allegations, Rohatyn says that Tudjman is "never anti-Semite but very pro-human. He's also compassionate and moving." Rohatyn wishes "truth were (as Tudjman suggests) all we needed to make peace." At any rate, he considers the text objective: "I don't find Tudjman to be proArab, either. He displays remarkable balance (no matter what Israeli partisans claim) and he's neither a demagogue nor an apologist....he's clearly a thinker, a man who contemplates all the horror yet goes on living. In conclusion, Rohatyn makes a plea for an end to "political correctness", 
which he considers "more sinister than anything Tudjman says."

In another review, a second Jewish-American professor writes that Horrors of War is an "unusual, thought-provoking, 'politically-incorrect' work, written by a "man for all seasons; and in advocating the scholar's values of accuracy and truth, he certainly appears to be head and shoulder above most political leaders today."

Even Croatian Jews weighed in with their comments. In the April 1996 "Jewish Currents", Dr. Srdjan Matic, former Vice President of the Jewish Community center in Zagreb, is quoted by the interviewer, Ira Leibowitz:

Dr. Matic tells me he met with Franjo Tudjman, who is not an anti-Semite but a right of center nationalist.... Dr. Matic has read Tudjman's controversial book. Denying a widely reported view, Matic asserts that falsified translations circulated by one Serb public relations firm were used to claim that Tudjman denies the Holocaust and the number of Jews murdered in it.

In a letter to the Times Literary Supplement, July 1993, Slavko Goldstein stated:

Tudjman is not an anti-Semite, not a fascist, and not a warmonger.

In two additional unpublished and informal reviews of the book by Jewish reviewers, Horrors of War is characterized as "a significant contribution to political and social history" and a "significant historical document", which "offers a new perspective on Croatian and Yugoslav history, using archival sources" and "emphasizes the importance of the scholars' goals of seeking accuracy and truthfulness when writing history, even though doing so may offend the powerful and/or the public." There were countless other such comments, both on and off the record, which support the same view. Nonetheless, the controversy and distortions continued, the double standard persisted. What was acceptable for others to research, evaluate, and deconstruct was apparently unacceptable for Croatia, and specifically for President Tudjman. Perhaps in acknowledgment of the fact that the manipulations and misunderstandings would continue, and that they were often independent of the facts, President Tudjman decided to make revisions of certain 
portions of his text which could be misconstrued or which tended to create an inaccurate representation of the Jewish people or of the President's views toward them, in spite of the advice of many others, Jews and non-Jews, who felt the book was in no way anti-Semitic and should not be changed. It is this revision which will now be available from M. Evans and Company, an American independent publishing house founded in 1960 and based in New York. M. Evans and Company publishes twenty to thirty books a year, and included among their best selling titles are: Meeting at Potsdam by Charles L. Mee, Dungeon, Fire and Sword: The Knights Templar of the Crusades by John J. Robinson, and Ides of August: The Berlin Wall Crisis by Curtis Cate. The introduction was written by the Honorable Thomas Patrick Melady, former U.S. Ambassador to the Holy See and President Emeritus of Sacred Heart University, an independent university which especially values intellectual research, social responsibility and spiritual values.

Very much in accordance with these basic concepts of the university of which he was President, Melady emphasizes Dr. Tudjman's success in reconciling the intellectual and the human in his examination of the phenomena of aggression and violence throughout the sweep of history:

\section{Tudjman examines the record of wartime Yugoslavia, and traces the purposes and processes behind the creation of the Croatian 'black legend'. At the same time, the author does not lose sight of the fact that each statistic was a human life. Having experienced the horrors of the Second World War himself, and having lost several members of his own family in the fighting, Tudjman understands like few other scholars that the horror of the Holocaust cannot be reduced to a statistical exercise, but must be understood in terms of the individual lives ended out of hate and ignorance.}

Ambassador Melady also places "Horrors of War" into a wider context, characterizing it as "many things: a political memoir, intellectual tour $\mathrm{d}$ force, a political document of an important period in the country's history and a broad historical philosophical survey." He believes readers will have a "candid insight into the mind of one of the most important statesmen in contemporary Europe. 'Horrors of War' is a contribution to the efforts of all people of good will 
to learn about the alienations of the past so that they will not be repeated."

It now to be hoped that the forces of deconstruction, and not "political correctness" will aid us in this process.

\section{Myth and reality in the decade of deconstruction}

In our consideration of the context in which President Tudjman's Horrors of War originated and the context in which it now finds itself, so many years later, we are aided by the decline of political correctness in academia and the rise of the forces of deconstruction. It is no longer fashionable to cloak but to expose the essence of things. Myths have been toppled, ideologies as well as reputations dismantled and discredited. What served before as history and incontrovertible fact has now in many instances been exposed as propaganda, opportunism, or simply shoddy research. What would have earlier been considered inappropriate and unacceptable avenues of research are now receiving extensive attention and even, in some cases, validation.

Much of this deconstruction has been occasioned by the fall of Communism and supported by previously closed Soviet archives. Perhaps the most controversial result of research into these archives is a 1995 Yale University Press publication "The Secret World of American Communism" by researchers Harvey Klehr, John Earl Haynes and Fridrikh Igorevich Firsov. Basing their conclusions upon the extensive, heretofore inaccessible documents, the authors show that "it is no longer possible to maintain that the Soviet Union did not fund the American (Communist) party, that the CPUSA did not maintain a covert apparatus, that the key leaders and cadres were innocent of connection with Soviet espionage operations." The Party was not comprised, as American Communists had always argued, of dissenters from capitalism or rebels in the democratic tradition, but was, rather "a conspiracy financed by a hostile foreign power that recruited members for clandestine work, developed an elaborate underground apparatus, and used that apparatus to collaborate with espionage services of that power." In other words, the charges were not a result of paranoia or extremist allegations, say the authors. There was in fact a secret Communist apparatus; this body did infiltrate government agencies; and many of these Communists did indeed spy for the Soviet Union, as their critics had alleged. 
This particular deconstruction has had extensive repercussions in the United States, as it has forced a reevaluation of not only the McCarthy investigations headed by the House Un-American Activities Committee in the 1950s, and the Alger Hiss and Rosenberg espionage cases, but of the American left in its totality.. Anthony Lake recently felt the influence of these disclosures when he was quizzed by the head of the Senate Intelligence Committee, Richard Shelby, on his views about the innocence or guilt of Hiss and the Rosenbergs. The question seems to have been whether Lake's former alleged leftist affiliations would prevent him from objectively analyzing intelligence data and whether he would have reached the same conclusion as Klehr, et al: that the archives dispel the misinformation that "concern about domestic Communism in the late 1940s and 1950s was without justification and constituted an authoritarian, anti-democratic attack on a movement whose only sin was to dissent from prevailing norms."

Another area which has been influenced by the fall of Communism and the opening of the Soviet archives is that of Holocaust research and research into the Second World War. Some of the recent publications on these subjects have certainly been a direct or indirect result of this contemporary trend toward deconstruction and research into hitherto "politically incorrect" topics.

How else to explain the emergence of Daniel Goldhagen's controversial book, "Hitler's Willing Executioners", in which he argues that Germans as a nation, and not as individuals, were anti-Semitic and enthusiastically cooperated with the Nazi regime in the eradication of the Jews? The notion of collective guilt has enjoyed virtually no support in the past (except, it could be argued, when applied to Croatia). One of the strongest attacks against the concept has come from critics of the US's forcible internment of native-born Americans of Japanese descent during the Second World War on grounds of questionable loyalty. Yet today, the collective guilt theory has been resurrected in Goldhagen's book, and subsequently used by the Czech constitutional court in a recent decision holding the German people "collectively responsible" for Nazi atrocities, and thereby rejecting Sudeten Germans' claims for compensation. Even the Nuremberg Tribunal explicitly rejected such a principle.

Another "politically incorrect" area of research: a work in progress by Yale graduate Byron Rigg on the approximately 
100,000 Jewish soldiers who fought in Hitler's army and who were provided with Aryan identification papers, and thus saved, by, among others, Hitler himself and Goering.

Let us also consider the memoirs of one of the foremost and most respected Holocaust historians, Raul Hilberg, "The Politics of Memory", which chronicle the attacks against him, which began thirty five years ago for his book "The Destruction of the European Jews." In it, he had written about Jewish institutions in the Second World War which served as an extension of the German bureaucratic machine, and the active role of the Jews in their own destruction, a direction which "was the exact opposite of a signal that pulsated endlessly through the Jewish community," a signal which rejected any attempts to "portray Jews as less than heroic." As a result, he was "buried under an avalanche of condemnations" and attacked as "impious" and as a "defamer of the dead" by his critics for over thirty years. Only now has he written about these painful years.

A new study and subsequent re-evaluation of statistics on Auschwitz victims has also appeared, "Anatomy of the Auschwitz Death Camp", edited by Michael Berenbaum, director of the U.S. Holocaust Memorial Museum's research department. According to a review of the book, the figure of 3-4 million who had perished in the camp had been uncritically accepted in the past, but has now been shown to have probably been inaccurate, based as it was upon erroneous statements by war criminal Adolf Eichmann. Most experts now place the figure closer to 1.1 million, and the overall number of victims of the Holocaust at $5.1-5.9$ million. In his review, Walter Lacqueur, prolific author himself and expert on international relations and the Holocaust, attempts to explain the discrepancy between such figures. "The truth,", he writes, "was difficult to establish There were enormous gaps in the source materials, and the Nazis did their best to obliterate the traces of their crimes." He further points out that "there were even greater discrepancies in every other known mass murder in history" and specifically mentions Serb victims in Croatia between 1941-44, for whom "estimates vary from none to $600,000 "$. In conclusion, Lacqueur says that the "experts who have reinvestigated the number of Auschwitz victims should be commended. It is a terrible subject, and their work could not have been easy for them." 
And especially not for President Tudjman, who turned his attention - far in advance of the currents of intellectual analysis and investigation currently in vogue - to related areas of research. In the new intellectual climate which produces and even supports investigations similar to those of Berenbaum, Goldhagen and Hilberg, it is to be expected that Horrors of War will finally receive the serious and objective attention it deserves. If not, one will be forced to conclude, as Orwell did, that "all animals are equal, but some are more equal than others." 